\title{
Striatum Involvement in LGI1 Limbic Encephalitis
}

\author{
Domenico Plantone
}

Neurology Unit, A.S.L. Verbano-Cusio-Ossola, Omegna, Italy

\section{TO THE EDITOR}

Kim et al. ${ }^{1)}$ recently reported a 37-year-old male patient with LGI1-related limbic encephalitis (LE) who presented with recurrent episodes of selective amnesia, seizure-like activity, confusion, and personality change. The patient showed a significant improvement after steroid therapy. Interestingly, the patient also presented intermittent sensory symptoms described as "flow of an electric current" and "seizure-like shivering". Sensory symptoms have been extensively described in patients with LGI1-antibody encephalitis. $^{2,3)}$ These patients experience multifocal seizure localisations with multiple semiologies, in addition to the characteristic faciobrachial dystonic seizures (FBDS) and some of them may remain subclinical. ${ }^{2)}$ In a recent paper by Aurangzeb et al., ${ }^{2)}$ sensory semiologies were reported to be as common as FBDS, and were most frequently thermal or shivering sensations.

Five years ago, I reported a 30-year-old patient with right FBDS associated with serum positivity of LGI1 antibodies and gadolinium-enhancing lesion involving the left caudate and globus pallidus." After about one year, this patient relapsed during low-dose tapering regime of prednisolone and the relapse did not consist in FBDS, but was characterized by brief and frequent episodes (approximately 40 per day) of tingling and numbness involving the right arm and face. These sensory seizures showed a complete response, after increasing the dosage of prednisolone. Voltage gated potassium channel (VGKC)complex/LGI1-antibodies test resulted positive at the time

Received: August 14, 2018 / Accepted: September 7, 2018 Address for correspondence: Domenico Plantone, $\mathrm{MD}, \mathrm{PhD}$ Neurology Unit, A.S.L. Verbano-Cusio-Ossola, Via Giuseppe Mazzini 117, 28887 Omegna (VB), Italy

Tel: +39-3205506307, Fax: +39-0324491200

E-mail: domenicoplantone@hotmail.com

ORCID: https://orcid.org/0000-0001-6666-7244 of relapse and ictal and interictal electroencephalograms (EEGs) were still normal (Plantone, 2016, unpublished data).

There are two points that should be highlighted. The first one regards the characterization of these sensory episodes. It is still controversial whether these episodes can be classified as "sensory epileptic auras" not followed by FBDS or as "pure sensory seizures". In fact, sensory auras have been reported to precede some motor events during the course of the disease. EEG changes are not frequently recorded during these sensory seizures. One can speculate that the sensory symptoms experienced by LGI-1 LE patients could be related to the involvement of the striatum. There are very interesting evidences in literature supporting striatal epileptogenicity, ${ }^{5)}$ and the absence of EEG changes could be an indirect evidence of the so called "subcortical epileptic seizures" in LGI1 LE patients. Strictly linked to the first, the second point of this discussion regards the involvement of striatum in sensory responses. For a long time, striatum has been regarded as a virtually pure motor structure, even if there were old studies focusing on sensory properties of striatal neurons. ${ }^{6)}$ Substantial evidence indicates that dorsolateral striatal neurons respond to sensory stimulation; however, the origin of these sensory inputs is still matter of debate. ${ }^{7)}$ Some authors support the hypothesis that these inputs come almost entirely from sensorimotor cortex, ${ }^{8,9)}$ whereas others suggest that other brain regions play a significant role $\mathrm{e}^{10-13)}$ and they focus particularly on several thalamic nuclei involved in processing sensory information, projecting to the dorsal striatum. Primarily the centromedianparafascicular complex and potentially also posteromedial nucleus may have both a significant influence on striatal sensory responsiveness. ${ }^{10)}$ One can argue that the involvement of the striatum can be demonstrated with clinical magnetic resonance imaging in a significant percent-

(ㄷ) This is an Open-Access article distributed under the terms of the Creative Commons Attribution Non-Commercial License (http://creativecommons.org/licenses/by-nc/4.0) which permits unrestricted non-commercial use, distribution, and reproduction in any medium, provided the original work is properly cited. 
age of the patients with LGI1 LE ${ }^{14)}$; however, the transient nature of this signal alteration and the lack of advanced imaging sequences in routine clinical practice may underestimate the involvement of striatum in LGI1 LE pathogenesis.

In conclusion, the debate on the clinical, radiological and neuropsychological features of LGI1 LE is helping to better characterize the pathogenesis of the disease, and will probably further clarify the role of the brain the structures involved.

\section{REFERENCES}

1. Kim SY, Um YH, Lim SC, Jeong JH. Limbic encephalitis manifesting as selective amnesia and seizure-like activity: a case report. Clin Psychopharmacol Neurosci 2018;16:109-113.

2. Aurangzeb S, Symmonds M, Knight RK, Kennett R, Wehner T, Irani SR. LGI1-antibody encephalitis is characterised by frequent, multifocal clinical and subclinical seizures. Seizure 2017:50:14-17.

3. Irani SR, Stagg CJ, Schott JM, Rosenthal CR, Schneider SA, Pettingill P, et al. Faciobrachial dystonic seizures: the influence of immunotherapy on seizure control and prevention of cognitive impairment in a broadening phenotype. Brain 2013;136:3151-162.

4. Plantone D, Renna R, Grossi D, Plantone F, lorio R. Teaching neurolmages: basal ganglia involvement in facio-brachial dystonic seizures associated with LGI1 antibodies. Neurology 2013;80:e183-184.

5. Badawy RA, Lai A, Vogrin SJ, Cook MJ. Subcortical epilepsy? Neurology 2013;80:1901-1907.
6. Albe-Fessard D, Rocha-Miranda C, Oswaldo-Cruz E. [Activity evoked in the caudate nucleus of the cat in response to various types of afferent stimulation. II. Microphysiological study]. Electroencephalogr Clin Neurophysiol 1960;12:649-661. French.

7. Wilson CJ. The sensory striatum. Neuron 2014;83:999-1001.

8. Pidoux M, Mahon S, Deniau JM, Charpier S. Integration and propagation of somatosensory responses in the corticostriatal pathway: an intracellular study in vivo. J Physiol 2011;589: 263-281.

9. Reig R, Silberberg G. Multisensory integration in the mouse striatum. Neuron 2014;83:1200-1212.

10. Alloway KD, Smith JB, Mowery TM, Watson GDR. Sensory processing in the dorsolateral striatum: the contribution of thalamostriatal pathways. Front Syst Neurosci 2017;11:53.

11. Alloway KD, Smith JB, Watson GD. Thalamostriatal projections from the medial posterior and parafascicular nuclei have distinct topographic and physiologic properties. J Neurophysiol 2014;111:36-50.

12. Smith JB, Mowery TM, Alloway KD. Thalamic POm projections to the dorsolateral striatum of rats: potential pathway for mediating stimulus-response associations for sensorimotor habits. J Neurophysiol 2012;108:160-174.

13. Mowery TM, Harrold JB, Alloway KD. Repeated whisker stimulation evokes invariant neuronal responses in the dorsolateral striatum of anesthetized rats: a potential correlate of sensorimotor habits. J Neurophysiol 2011;105:2225-2238.

14. Flanagan EP, Kotsenas AL, Britton JW, McKeon A, Watson RE, Klein CJ, et al. Basal ganglia T1 hyperintensity in LG/1-autoantibody faciobrachial dystonic seizures. Neurol Neuroimmuno/ Neuroinflamm 2015;2:e161. 